\title{
8
}
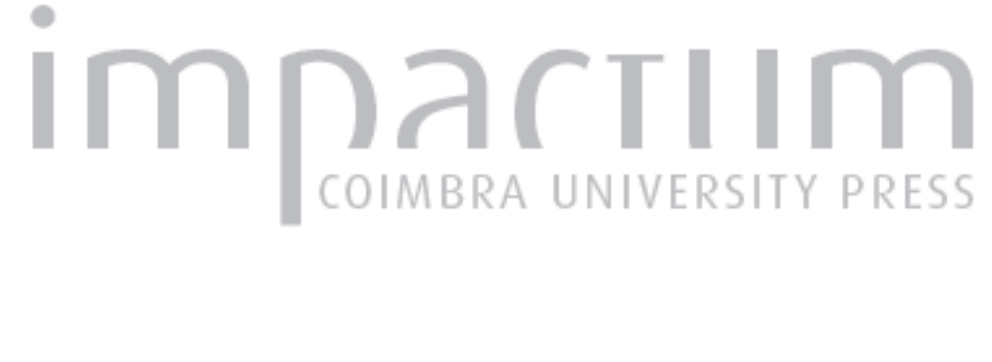

Exemplo ou contraexemplo? O caso de uma estátua nas Enéadas de Plotino

Autor(es): Baracat Júnior, José

Publicado por: Annablume Clássica

URL

persistente: URI:http://hdl.handle.net/10316.2/24323

Accessed : $\quad$ 26-Apr-2023 13:19:18

A navegação consulta e descarregamento dos títulos inseridos nas Bibliotecas Digitais UC Digitalis, UC Pombalina e UC Impactum, pressupõem a aceitação plena e sem reservas dos Termos e Condições de Uso destas Bibliotecas Digitais, disponíveis em https://digitalis.uc.pt/pt-pt/termos.

Conforme exposto nos referidos Termos e Condições de Uso, o descarregamento de títulos de acesso restrito requer uma licença válida de autorização devendo o utilizador aceder ao(s) documento(s) a partir de um endereço de IP da instituição detentora da supramencionada licença.

Ao utilizador é apenas permitido o descarregamento para uso pessoal, pelo que o emprego do(s) título(s) descarregado(s) para outro fim, designadamente comercial, carece de autorização do respetivo autor ou editor da obra.

Na medida em que todas as obras da UC Digitalis se encontram protegidas pelo Código do Direito de Autor e Direitos Conexos e demais legislação aplicável, toda a cópia, parcial ou total, deste documento, nos casos em que é legalmente admitida, deverá conter ou fazer-se acompanhar por este aviso. 

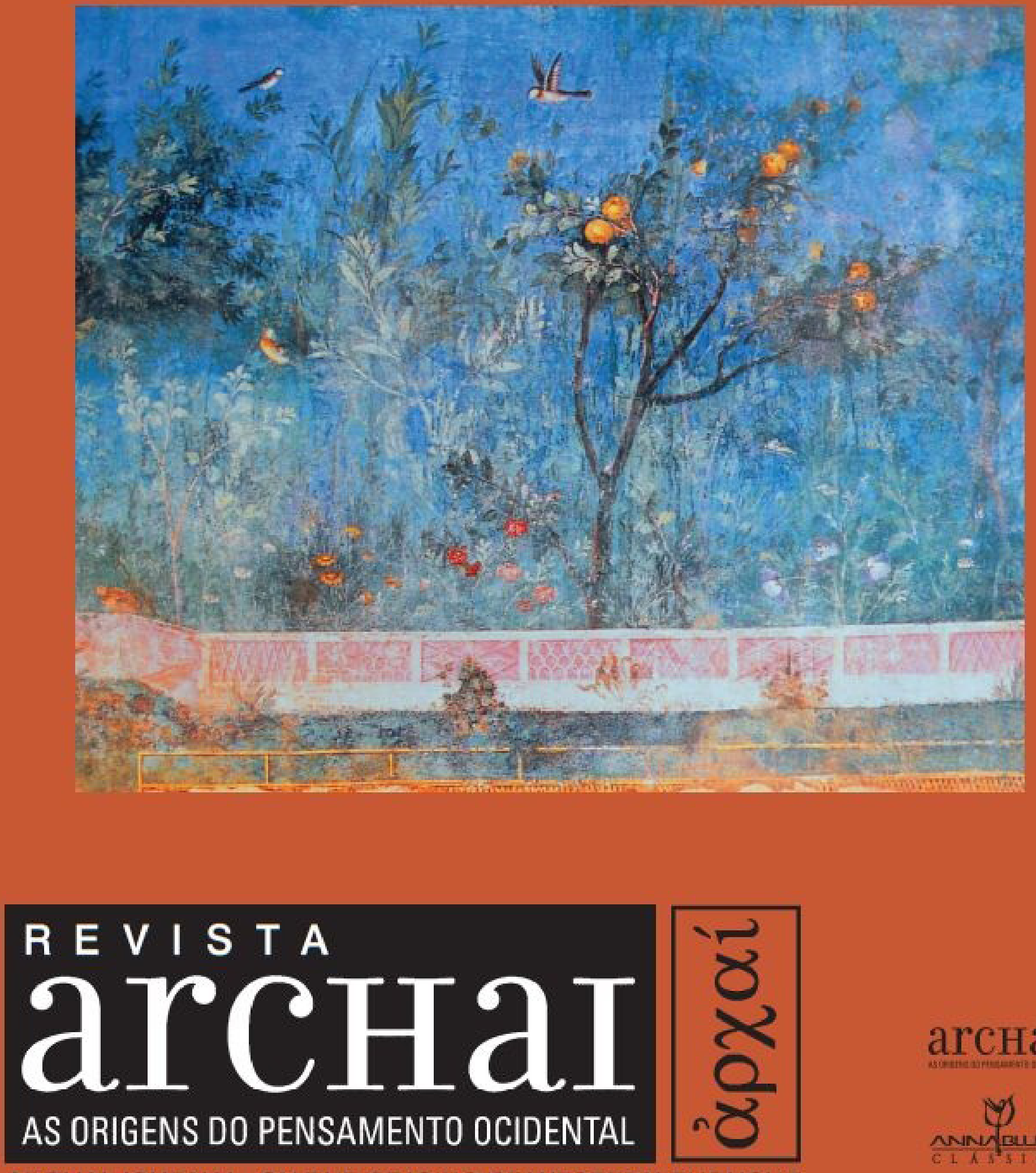

arcнаI

ARCHAI JOURNAL: ON THE ORIGINS OF WESTERN THOUGHT

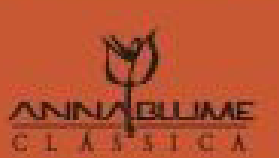




\section{EXEMPLO OU CONTRAEXEMPLO? 0 CASO DE UMA ESTÁTUA NAS ENÉADAS DE PLOTINO}

BACARAT JÚNIOR, J. (2013). Exemplo ou contraexemplo? 0 caso de uma estátua nas Enéadas de Plotino. Archai, n. 10, jan-jul, p. 73-84.

RESUMO: Este artigo é uma reflexão acerca de um exemplo dado por Plotino - a estátua do Zeus Olímpio de Fídias, em V. 8 [31] 1. 38-40 - para ilustrar uma tékhne que não é mímesis da natureza. Meu objetivo é verificar se o Zeus de Fídias de fato exemplifica tal tékhne, averiguando a consistência desse exemplo e sua coerência com as considerações plotinianas sobre a beleza e as artes. Embora sugira algumas interpretações para o exemplo, este trabalho é inconclusivo, uma vez que apenas coloca o exemplo em dúvida.

PALAVRAS-CHAVE: Plotino (c. 205-271) - Fídias - estética - arte - imitação - contemplação.

ABSTRACT: This paper is a reflection on an example given by Plotinus - Phidias' statue of the Olympian Zeus in V. 8 [31]. 38-40 - in order to illustrate a tékhne which is not mimesis of nature. My aim is to verify whether Phidias' Zeus actually exemplifies such tékhne, inquiring the consistency of this example and its coherence with Plotinus' accounts of beauty and the arts. Although it suggests some a few interpretations of the example, this article is inconclusive, since it only casts doubt on the example.

KEYWORDS: Plotinus (c. 205-271) - Phidias - aesthetics - art - imitation - contemplation
José Baracat Júnior *

\section{i. A arte não imita a natureza}

Eis uma das passagens da filosofia antiga mais citadas em manuais, histórias, companions e obras do gênero dedicadas à estética e à teoria da arte ${ }^{1}$ :

Estejam, pois, se queres, duas massas de pedra postas uma ao lado da outra; uma delas é sem modelagem e sem participação de uma arte, a outra já dominada pela arte e transformada em estátua de um deus ou de algum homem - um deus como uma Graça ou uma Musa, e um homem, não um qualquer, mas um que a arte produziu a partir de todas as coisas belas [ôv

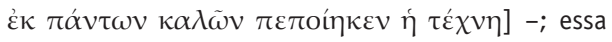
pedra, transformada pela arte na beleza de uma forma, aparecerá bela não por ser pedra - pois assim a outra também seria igualmente bela - mas sim por causa da

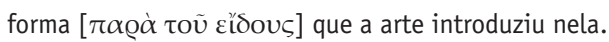
Essa forma, portanto, a matéria não a possuía, mas ela estava naquele que a concebeu mesmo antes de advir à pedra; e ela estava no artista [غ่v $\tau \tilde{\omega} \delta \eta \mu$ tov@ $\gamma \tilde{\omega}$ ] não porque ele tem olhos e mãos, mas porque ele participava da arte. Então, na arte, essa beleza era muito superior; pois não é aquela beleza que estava na arte a beleza que veio à pedra, aquela permanece, mas sim uma outra, derivada da arte, inferior àquela; e essa beleza não permaneceu pura em si mesma nem 
tal como ela desejava, exceto na medida que a pedra cedeu à arte. Se a arte produz conforme o que ela é e possui - e produz beleza de acordo com a razão

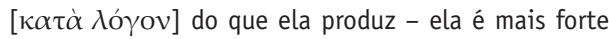
e verdadeiramente bela por possuir a beleza da arte, que é superior e mais bela do que tudo quanto há no exterior. De fato, quanto mais ela se dilata adentrando a matéria, tanto mais ela se torna fraca em relação à arte que permanece em unidade. Pois tudo que se distende se afasta de si mesmo, se força em força, se calor em calor e, em geral, se potência em potência, se beleza em beleza. E todo produtor primário deve ser por si mesmo superior ao produto; pois a obra musical não é produzida pela ausência de música, mas pela música, e a música sensível é produzida por uma música anterior a ela. E se alguém despreza as artes porque elas produzem imitando a natureza, deve-se dizer a ele, em primeiro lugar, que também as naturezas imitam outras coisas. Em seguida, deve-se saber que elas não imitam simplesmente o que visto, mas recorrem às

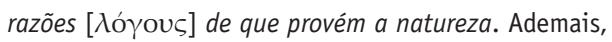
elas produzem muitas coisas a partir de si mesmas e acrescentam a essas coisas o que lhes falta, uma vez que são possuidoras da beleza; pois mesmo Fídias não fez seu Zeus conforme nenhuma coisa sensivel, mas tendo-o concebido tal como Zeus seria, se desejasse aparecer aos nossos olhos'.

Não é difícil imaginar por que essa passagem seja sempre tão lembrada. Com a celebridade do banimento dos poetas, das artes miméticas de modo geral, da República de Platão (597b-598c), essa defesa entusiasmada da arte soa como uma insurgência irresistível, ainda mais porque vinda do interior do próprio platonismo. Finalmente os filósofos platônicos poderiam entregar-se à fascinante arte de Homero sem culpa. A produção artística recebe uma defesa filosófica de tal vigor, que, praticamente sozinho, Plotino reabre as portas da cidade para os poetas, permitindo aos neoplatônicos que 0 sucederam reabilitarem brilhantemente 0 "pai dos gregos", como o fizeram Porfírio e Proclo ${ }^{3}$. Torna-se possível não apenas ler Homero com dignidade, mas encontrar nele os ensinamentos que estão, velada ou desveladamente, nas obras do próprio Platão. A exegese alegórica de Homero é bem anterior a
Plotino, mas a exegese alegórica que lê Platão em Homero é tipicamente plotiniana ${ }^{4}$.

Na passagem citada acima, o que nos admira, inicialmente, é que a produção natural também seja imitação; é imitação necessária, espontânea, não deliberada, mas também é imitação. Basta-nos passar os olhos por alguns capítulos do tratado Sobre a Natureza, a Contemplação e o Uno (III. 8 [30] 2-4), para entendermos que a natureza é um eîdos, o lógos do noûs, que produz o universo sensivel inserindo lógos na matéria informe através da contemplação da herança noética recebida da alma superior. A arte produzida pelo homem, por sua vez, também é mímesis; entretanto, ela não é imitação ou representação da natureza, como sugerira Platão, mas daquilo mesmo que dá origem à natureza, os princípios formativos intelectuais contidos no intelecto. Portanto, o artista produz sua arte através da contemplação imediata do inteligivel e pode - outro ponto que causa admiração - produzir com mais beleza e perfeição do que a natureza, pois pode contemplar com mais intensidade do que ela ${ }^{5}$.

Tudo quanto vemos no universo sensível, a obra de arte da natureza, é belo, mas o homem é capaz de interferir na obra natural e produzir uma obra ainda mais bela, como no exemplo citado por Plotino: o homem é capaz de incutir forma na matéria originada pela natureza e, assim, insuflar beleza na natureza, transformando uma pedra amorfa na estátua de um deus ou um belo humano. Essa forma incutida pelo homem na natureza foi apreendida por ele diretamente a partir da contemplação do inteligível; ela estava ausente da natureza e veio da contemplação do artista para a matéria. Entretanto, para Plotino, a beleza produzida pelo artista é menos bela que a beleza por ele contemplada, mas mais bela e verdadeira que a beleza percebida pelos sentidos, pois a materialização, isto é, a expressão da forma intelectual através de seu reflexo na matéria, causa diminuição da unidade e, por consequência, diminuição da perfeição ontológica. Nas já muito citadas palavras de Emile Bréhier, a estética plotiniana é uma "estética expressionista, segundo a qual a beleza exprimida nas coisas é sempre deficiente em relação à beleza interior que ela aspira a exprimir: a beleza está também na arte e no artista muito
2. V. 8 [31] 1. 6-40. Pus em itálicos passagens a que pretendo fazer referir-me. Todas as traduções são minhas e seguem a editio minor de Henry e Schwyzer (1964-1982).

3. Cf. Buffière, 1973, p. 27

4. Em I. 6 [1] 8, por exemplo, numa página digna dos momentos mais grandiosos de Platão, Plotino usa a odisséia de Odisseu como legoria do retorno da alma errante neste mundo sensivel para o inteligível: "'Fujamos para a pátria querida', alguém exortaria com maior verdade [Homero, Ilíada II, 140]. Então, que fuga é essa? Como? Navegaremos como Odisseu, diz ele [Homero] enigmando, penso eu -, que fugiu da feiticeira Circe ou de Calipso [Odisséia, IX, 29ss. e X, 483-4], não contente em permanecer, embora tivesse prazeres para os olhos e se unisse a muita beleza sensível. Nossa pátria é donde viemos e nosso pai está lá. Que jornada e que fuga são essas, portanto? Não devemos perfazê-la com os pés: os pés nos levam a todo lugar, da terra para terra; e não precisas preparar uma carruagem de cavalos ou uma embarcação, porém deves te afastar de tudo isso e não olhar, mas, como que cerrando os olhos, substituir essa visão e despertar uma outra, que todos têm, mas poucos usam".

5. A natureza é dotada de uma contemplação mais turva, mais débil que a da alma e, por isso, seu produto é inteiramente débil (III. 8 [30] 4). Não analisarei aqui a distinção entre a capacidade contemplativo-produtiva da natureza e a da alma, mas podese estabelecer o seguinte: a natureza permanece num nível contemplativo estável, ao passo que a alma, especificamente a alma humana, ocupa níveis diferentes, conforme a intensidade da atividade contemplativa a que ela se propõe, podendo estar mais próxima dos animais bem como ser o próprio noûs (cf. IV. 8 [6]. 1. 1-11, onde Plotino descreve sua estada no noûs e seu retorno ao corpo, um tipo de movimento anímico que Plotino jamais associa à natureza nas Enéadas). 
6. Bréhier, 1931, p. 128 7. Não me estenderei sobre 0 tema complexo neste artigo; permito-me remeter a um artigo que escrevi especificamente sobre o modo como III. 8 [30] fundamenta filosoficamente a arte: Baracat, 2007.

8. III. 8 [30] 7. 1-2.

9. Ibid., 7. 21-22.

10. Ibid., 1. 4. Cf. a observação de Armstrong (1966-1988, vol. III,

p. 200, nota): “Esse [a distinção entre prâxis-poíesis e theoría] é um dos princípios fundamentai do pensamento filosófico grego, que recebe aqui uma aplicação especial. Fazendo da theoría o fim de toda percepção e ação, Plotino

abole, sem dúvida consciente e deliberadamente, a distinção de Aristóteles entre praktiké e theoretiké epistéme ou diánoia e transforma toda a vida, não apenas a do homem, mas a do universo, em filosofia no sentido de Aristóteles". 11. Duas opiniões são significativas; primeiro a de Aubenque (1973, p. 210): “Assim a filosofia de Plotino se revela finalmente preocupada com aquilo mesmo que, num primeiro momento, parecia querer rejeitar: o sensível, o mundo, a alm humana, a matéria - fonte da divisão do Uno, mas também da composição dos seres - a temporalidade, lugar e princípio de toda constituição"; e também a de Alliez (1991, p. 128, n. 119, com várias referências a Deleuze):

“Mas fazer da própria degradação uma afirmação...aí está também

o grande lance de Plotino...E toda 'a potência de uma qued profunda' é necessária 'para chegar a esse ponto', até essa 'ética' das quantidades intensivas - segundo bela expressão de Gilles Deleuze

- cujo lugar de emergência vemos nas Enéadas. 'Construída sobre duas séries, pelo menos, superior e inferior, sendo que cada série por sua vez remete a outras séries implicadas, a intensidade afirm até mesmo o mais baixo, faz do mais baixo um objeto de afirmação (...). Não há profundidade que não 'vasculhe um bas-fond: é ai que a distância se elabora como afirmação do que ela distancia, a diferença como afirmação do baixo'

(Différence et répétition, Paris, 1968, p. 375)"

12. "A arte dá beleza a toda uma casa com suas partes e, noutras, uma natureza o faz a uma única pedra. Assim, pois, o corpo belo surge da comunhão com uma razão provinda dos seres divinos. mais que na obra [...] Plotino defende uma arte idealista, na qual o artista rivaliza com a natureza e faz melhor do que ela" ${ }^{6}$.

A possibilidade dessa arte é fundamentada por Plotino em III. 8 [30] $]^{7}$. Conforme esse escrito, toda a realidade, sensível ou inteligível, provém da contemplação e é contemplação ${ }^{8}$, e produzir é fazer uma forma existir, isto é, preencher todas as coisas com contemplação ${ }^{9}$. E toda atividade humana é, em última instância, contemplação; toda poíesis e toda prâxis são theoría. A obra de arte é o resultado de uma atividade realizada pelo artista; mais especificamente, a obra de arte é um poíema de uma poíesis, o resultado de uma produção. Essa concepção idealista da arte decorre de um movimento que, por assim dizer, inverte a ordem do mundo platônico e, apesar disso, torna o mundo ainda mais platônico. Se tudo é imitação de um princípio superior, e se para imitar é preciso contemplar, então tudo contempla e tudo é contemplação - "inclusive as plantas e a terra que as engendra" ${ }^{10}$-; se tudo é imitação, ser imitação não é por si mesmo algo reprovável ${ }^{11}$ : a imitação não é, portanto, uma negação da verdade ou da beleza, mas a afirmação de que há verdade e beleza em todas as coisas.

\section{ii. A arte imita a natureza}

Apesar de Plotino sustentar a possibilidade de uma arte que não imita a natureza através de uma tese que não ocorre e que não pode ser facilmente rastreada em nenhuma passagem das Enéadas a não ser em III. 8 [30] - a tese de que a poíesis é contemplação -, existe, desde os primeiros tratados, uma certa convicção de que há algo na obra de arte que não pertence à natureza. Textos como I. 6 [1] 2. 24-3.9 ${ }^{12} \mathrm{e}$ V. 9 [5] 5. 38-41 ${ }^{13}$ insistem em que a arte, através do artista, insere uma forma imaterial na matéria e que a beleza é, justamente, a unidade inteligível que essa forma confere à matéria amorfa e múltipla.

Todavia, há uma outra face de Plotino: não são insignificantes as passagens das Enéadas que atribuem à arte um valor secundário em relação à natureza e que seguem à risca a condenação anunciada por Platão no décimo livro da República. As mais importantes, ou pelo menos as mais conheci- das e explícitas, são IV. 3 [27] 10.17-19 ${ }^{14}$ e Vida de Plotino, 1, 4-9. Na Vida, Porfírio nos conta que Plotino, ante a insistência de Amélio para que se deixasse retratar, respondeu:

Tolerar um pintor ou um escultor the parecia tão indigno a ponto de responder a Amélio, que the pedira permissão para que se fizesse um retrato dele: “Não basta carregar a imagem com que a natureza nos revestiu", mas se the pedia ainda que concordasse em

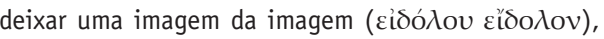
mais duradoura, como se essa fosse de fato alguma das obras dignas de serem contempladas?

Pode-se pensar que uma opinião tão depreciativa da arte fosse uma apenas resposta à insistência inconveniente de Amélio, ou ainda uma certa modéstia ou timidez. Mas a ideia que ecoa dessa recusa encontra um paralelo direto em duas passagens das Enéadas. Em VI. 3 [44] 15. 29-37, Plotino usa Sócrates como exemplo para mostrar que o (1) retrato de Sócrates é derivado do (2) Sócrates empírico, que deriva do (3) lógos de Sócrates, que é derivado do (4) lógos de homem ${ }^{15}$.

\section{iii. Duas teorias inconciliáveis?}

Costuma-se pensar que a primeira teoria, a que considera que a arte tem princípios inteligíveis, seja antiplatônica, ao passo que a segunda, a que toma a arte como mera imitação da natureza, seja extremamente platônica. A verdade, ou pelo menos uma das verdades, é que a teoria platônica da arte é bem mais complexa do que eu, ou Plotino, possa ter dado a entender. A expulsão dos poetas da $R e$ pública é tão emblemática e tão clara, e o diálogo é tão célebre, que esta se tornou a posição platônica por excelência. Todavia, em Platão há indícios de uma distinção entre uma cópia legítima e um mero simulacro: P.-M. Schuhl (1933) já investigara o Sofista, por exemplo, para distinguir uma arte da cópia e uma arte do simulacro; e G. Deleuze (1969, 292ss.) também encontra um Platão que não é tão negativo a respeito da cópia.

Mas essa sutileza da filosofia platônica não passou despercebida pelos antigos, como faz notar 
J. Pépin (1992, 320-321), aduzindo um texto importante do Timeu (28 a-b) ${ }^{16}$ e um trecho do comentário de Proclo (In Tim., I. 265, 10-22 Diehl) ${ }^{17}$ sobre ele. No Timeu, há uma distinção entre as artes devida ao seu modelo: a arte que imita o inteligível produz 0 belo, a que imita o sensível produz o não-belo. É bem possível que Platão pensasse numa distinção entre o Demiurgo, o grande artista criador do universo, e os demais demiurgos. 0 que um filósofo perspicaz como Proclo retira do Timeu, sem dúvida influenciado pela reflexão de Plotino, é que a arte de modo geral pode ser boa ou má na proporção em que o artista é capaz de produzir olhando o inteligível ou o sensível. Fornecendo o mesmo exemplo do Zeus de Fídias, ele o interpreta como uma obra que não copia um modelo sensível, mas que se inspira no Zeus dos poemas homéricos. Cabe lembrar que Homero jamais descreve fisicamente Zeus, referindo-se a ele apenas como "pai dos deuses", "lançador de raios", "tonitruante" etc.; ou seja, Fídias concebeu uma estátua a partir de descrições da grandiosidade de Zeus. Se Fídias tivesse contemplado Zeus em si mesmo, ele teria feito sua magistral estátua ainda mais bela.

Minha perplexidade em relação ao exemplo dado por Plotino começa a se delinear, com o mesmo exemplo dado posteriormente por Proclo. Ora, segundo Proclo, Fídias não olhou para o deus em si mesmo, porém o concebeu a partir do Zeus de Homero: se ele não viu o próprio deus, por que sua arte é inteligível? Fídias apreende o Zeus de Homero sensivelmente, ouvindo a récita de um aedo ou, talvez, usando seus olhos para ler os poemas. Além disso, em que sentido essa concepção de produção pode ser mímesis? Como uma estátua de um deus antropomórfico é imitação de um trovão? Note-se, aliás, que Proclo se insinua menos idealista do que Plotino, pois dá a entender que a representação de algo imaginado, porém não fielmente copiado, já é garantia de certa qualidade artística.

Pépin se vale da interpretação de Proclo para explicar as duas teorias artísticas presentes na Enéadas e, assim, escapar à tentação de atribuir a discrepância ao improvável desenvolvimento da posição de Plotino em relação à arte ${ }^{18}$. Finberg (1926, p. 150) sugerira que Plotino tivesse revisto suas ideias em 263, quando Porfírio chegou a
Roma para ser seu discípulo; e De Keyser (1955, p. 32-51) foi ainda mais enfático nessa afirmação. 0 que desmonta a teoria da evolução do pensamento plotiniano, especificamente neste caso, é que tanto há traços da inteligibilidade da arte antes do tratado 31 (V. 8), quanto há afirmações contrárias em tratados posteriores a ele, como pode ser constatado nos tópicos i. e ii. deste artigo. Os defensores da evolução simplesmente desconsideram as passagens incômodas $^{19}$. Pépin, por sua vez, antecipa a explicação de Proclo para Plotino, entendendo que Plotino faça a mesma distinção entre as artes - a arte é superior se toma um modelo inteligível, inferior se imita um modelo sensível -, embora sem a clareza procliana.

A análise conciliatória das duas teorias plotinianas da arte realizada por Pépin é brilhante, erudita e sofisticada como tudo que esse grande intelectual produziu, e parece ser definitiva, pois nenhum estudo posterior, até onde vai meu conhecimento, a refutou ou acrescentou-lhe algo. E não é minha intenção, de modo algum, criticá-la. Apenas me parece que, embora encontremos fagulhas da teoria exposta em V. 8 [31] em tratados anteriores a ele, essa teoria só é plenamente fundamentada no tratado 30 (III. 8) através da demonstração de que a poíesis é theoría - e esta tese não se encontra em nenhum outro tratado anterior ${ }^{20}$. Plotino podia dar mostras de onde chegaria, mas talvez ainda não tivesse refletido profundamente sobre a questão. Contudo, não se pode descartar a hipótese de que Plotino não seja coerente a esse respeito, e que suas afirmações sejam muito motivadas pelos contextos e pelos interlocutores visados num ou noutro escrito.

\section{iv. 0 Zeus de Fídias}

a) 0 exemplo: suponhamos que Plotino seja coerente em suas opiniões sobre a arte; ou melhor, aceitemos que Plotino esteja mesmo entre o Timeu e Proclo, e que, afinal, Pépin tenha nos fornecido as ferramentas necessárias para compreender as duas estéticas de Plotino. 0 que é vital para mim, nesta reflexão, é que Plotino concebe e fundamenta uma teoria da produção artística segundo a qual existe uma arte que não imita a natureza, mas os lógoi inteligíveis de que a própria natureza procede. Em
A faculdade destinada ao belo 0 reconhece, e nenhuma outra é mais poderosa do que ela para julgar as coisas que the são próprias quando o restante da alma contribui no juízo, e talvez ela se pronuncie ajustando-o à forma que está com ela e usando-a para o juízo como um cânon de correção. Mas como o que diz respeito ao corpo consoa ao que é anterior ao corpo? Como 0 arquiteto diz ser bela a casa exterior, tendo-a ajustado à forma interior de casa? É porque a forma exterior, se abstrais as pedras, é a interior dividida pela massa exterior da matéria, sendo indivisivel ainda que se manifeste na multiplicidade".

13. "0 bronze <recebe uma forma> da arte estatuária e a madeira da arquitetônica, através de uma imagem da arte que vai até eles, mas a arte mesma permanece em identidade fora da matéria e possui a estátua e a cama verdadeiras".

14. "Pois a arte é posterior a ela [natureza] e a imita, produzindo imitações obscuras e fracas que são brinquedos e sem muito valor, empregando muitos artifícios para <a fabricação de> uma imagem da natureza". Outras passagens que também sustentam que a arte imita a natureza: V. 9 [5] 11. 1-6 VI. 4 [22] 10. 5-15; VI. 2 [43] 22. 33-46.

15. Sobre o episódio do retrato de Plotino e todas as questões que ele envolve, veja-se o artigo determinante de Pépin, 1992. 16. Cf. 28 a 6-b 2 Burnet: "Portanto, se o demiurgo olhar para aquilo que é sempre o mesmo, empregando um tal paradigma, ele produz sua ideia e potência, de modo que tudo que realiza é belo; mas, se $<0$ har> para algo que veio a ser, um paradigma engendrado, $<0$ resultado> não é belo".

17. "Aquele que produz tendo em vista o inteligível, ou o imita com semelhança, ou sem semelhança; se com semelhança, fará belo o imitado; se sem semelhança, não tem em vista 0 inteligível: pois, contrariamente, ele se afasta da semelhança. Mas aquele que produz tendo em vista o engendrado, se olha de fato para ele, evidentemente não produz o belo: pois isso mesmo < para o qual ele olha> pleno de dessemelhança e não é o primariamente belo: assim, o engendrado a partir disso será muito mais afastado da beleza. 
Pois também Fídias, o que produziu o Zeus, não olhou para algo engendrado, mas ele chegou à noção de Zeus em Homero; ele pudesse estender-se ao próprio deus intelectivo, sem dúvida teria feito sua própria obra mais bela". Segundo Porfírio (Vida de Plotino, 4. 9ss.), Plotino inicia sua atividade literária em 254 com quase cinquenta anos. Toda sua produção, a produção de um homem maduro e com convicções bem definidas, portanto, está concentrada em quinze anos. Por isso, a maioria dos plotinistas está de acordo que não haja modificação significativa no pensamento de Plotino; isso não exclui, contudo, pequenas mudanças de enfoque ou mesmo mudanças relativamente grandes em tópicos particulares.

19. Não se pense que o livro de De Keyser seja diminuído por isso ele continua sendo, em minha opinião, o livro mais completo sobre a arte em Plotino.

20. Permito-me a deselegânci

de novamente remeter a um artigo meu (Baracat, 2002) em que apresento um dossiê das ocorrências dos termos theoría theorein nos vinte e nove tratados anteriores a III. 8 [30]; nesse artigo, insisto na novidade e na singularidade dessa tese dentro do corpus plotiniano.

21. Apenas alguns pouco exemplos: Ésquines, In Ctesiphontem 150, 1; Aristóteles,

Ética a Nicômaco 1141a10 Diodoro Siculo, Bibliotheca historica 12, 1, 4, 6; Galeno, Quod optimus medicus sit quoque philosophus 1, 57, 2; De naturalibus facultatibus, passim; Isócrates, Antidosis 2, 4; Luciano De morte Peregrini 6, 4; Quomodo historia conscribenda sit 50,10;

Filo de Alexandria, De ebrietate 89, 2; Platão, Protágoras 311 c 3 ; Mênon 91 d 4; Plutarco, Péricles 2 , 1,$4 ; 13,6,2$ minha opinião pelo menos, tudo vai filosoficamente bem até Plotino apontar um exemplo para tal arte. Os estudiosos parecem contentar-se com o que Plotino e Proclo thes oferecem, investigando sua teoria (ou suas teorias) da arte para concluir que Fídias não copiou a natureza. 0 próprio Pépin (1992, p. 322) nos dá um exemplo excelente:

Pois a investigação através das Enéadas à qual procedemos mostra que apenas os artistas medíocres, que trabalham reproduzindo um modelo sensível, são compelidos a fazerem-no posar; Fídias não fizera Zeus posar, nem quem quer que seja, para representar Zeus, pois ele tomou como modelo apenas a representação do deus que sua piedade the sugeria.

Como indiquei acima, ao tratar de Proclo, não é fácil entender de que modo a estátua de Zeus não imite a natureza. À primeira vista, ao pensarem que Fídias não copiou nenhum homem sensível em particular, Plotino e Proclo parecem entender que Fídias contemplou algo inteligível. Mas é difícil aceitar que pensadores dessa envergadura pudessem se expor a uma objeção óbvia: quem pode garantir que o Zeus de Fídias não corresponde a nenhum modelo sensivel? Uma pergunta anacrônica: quem pode dizer se Fídias não viu seu modelo andando por Atenas e o guardou inconscientemente na memória, criando seu Zeus de acordo com essa lembrança inconsciente? A estátua devia representar um homem maduro, musculoso, barbado: mesmo que esse homem não corresponda a este ou aquele homem, uma composição de partes sensíveis de homens sensiveis não continua sendo um modelo sensível? Claro, há uma nítida diferença entre Cartério - o artista incumbido de representar Plotino (Vida de Plotino, 1, 19) - copiar exatamente Plotino e, por outro lado, Fídias representar um homem que não pose para ele e que não corresponda a nenhum homem particular - pelo menos a nenhum homem inteiro, já que o nariz pode ser de Alcibíades, a barba de Sócrates, e assim por diante. Além disso, que significa dizer que a estátua é "tal como Zeus seria, se desejasse aparecer aos nossos olhos"? Plotino pode ser classificado como pagão porque não é cristão, mas sua religiosidade é racional demais para, primeiro, acreditar em Zeus como um deus e, segundo, para concebê-lo com a forma humana. Para um grego contemporâneo de Fídias, Zeus era um deus para quem se faziam sacrifícios, a quem súplicas eram dirigidas, que era temido. As estátuas dos deuses, geralmente construídas no interior dos templos dedicados a esses deuses, eram consideradas pontos materiais de uma verdadeira teofania desses deuses. Mas, para Plotino, as estátuas não eram mais do que isso mesmo que elas nos parecem ser: estátuas, produtos de uma tékhne; e Zeus já não era mais do que aquilo que é para nós hoje: um personagem mitológico. Então, por que Zeus nos apareceria como um homem forte e barbudo?

A mesma dificuldade ocorre um pouco antes no texto de V. 8 [31] 1: Plotino diz que a arte domina a matéria para produzir "um homem, não um qualquer, mas um que a arte produziu a partir de todas as coisas belas" ( $\dot{\kappa} \kappa \pi \alpha ́ \alpha \tau \omega \nu \kappa \alpha \lambda \tilde{\omega} v)$ ); temos de ter certa boa-vontade para traduzir o texto dessa forma, pois poderíamos perfeitamente traduzir: “um homem que a arte produziu a partir de todos os homens belos", uma vez que o genitivo plural não nos permite distinguir o masculino (que confirmaria a tradução "a partir de todos os homens belos") do neutro, igualmente possivel, mas menos provável (que confirmaria "a partir de todas as coisas belas"). Escolhendo o neutro, tentamos salvar o texto de uma contradição evidente; contudo, essas "todas coisas belas" também requerem um pouco mais de boa-vontade para serem tomadas como a totalidade das formas inteligíveis.

b. A estátua: Plotino jamais viu a estátua de Fídias. No século $3^{\circ}$, nenhuma de suas obras estava preservada, salvo os relevos do Partenón. E não há nenhum indício de que Plotino tenha conhecido a Grécia; Alexandria e Roma foram suas duas metrópoles. Entretanto, visto que Fídias e suas obras são citados por um número realmente impressionante de autores como exemplos de perfeição artística ${ }^{21}$, não temos motivo para duvidar que Plotino conheça o Zeus de Fídias exclusivamente através de sua amplíssima fama no mundo antigo e por descrições literárias dele. Fídias, como exemplo de um escultor que não copiava a natureza, é também um exemplo 
dado por Cícero, no De oratore, II, 17 e 73 (sobre a sua Atena) e no Orator II, 8-III, 9 (sobre o Zeus e a Atena); esta última passagem, com efeito, é muito próxima da de Plotino ${ }^{22}$.

A maioria das referências às obras de Fídias não menciona nenhum traço físico objetivo das obras, apenas repetindo sua grandiosidade, sua perfeição e sua dessemelhança com qualquer humano em particular. A admiração é a tônica comum, com exceção de uma menção célebre. Calímaco, no seu sexto jambo, fornece uma descrição detalhadíssima do Zeus: um amigo está empolgado para ir a Olímpia contemplar a beleza da estátua de Fídias, e Calímaco, para poupar-lhe a viagem, dá-lhe todos os dados numéricos da estátua. Infelizmente, desse poema só nos restam fragmentos. Contudo, podemos extrair dele exatamente aquela imagem que todos temos quando pensamos em Zeus: a escultura, que representava Zeus sentado em seu trono, devia medir algo em torno de quinze metros de altura e devia resplandecer intensamente, pois era revestida com metal e pedras coloridas ${ }^{23}$. Para figurarmos melhor a impressão que tinha um espectador diante dessa estátua, por sorte contamos com uma passagem significativa de Pausânias, que possivelmente faz referência ao jambo de Calímaco, criticando-o por diminuir a magnificência da estátua ao reduzi-la a números, a mera medida:

Embora eu saiba que se escreveram as medidas de altura e de largura do Zeus em Olímpia, não apresentarei elogios aos medidores, porque as medidas relatadas por eles ficam muito aquém da impressão (dóxa) que a estátua suscita naqueles que a veem; por isso dizem que o próprio deus é testemunha da arte de Fídias. Pois, quando a estátua estava terminada, Fídias suplicou para que o deus the mostrasse se o trabalho estava de acordo com seu juízo: imediatamente, dizem, um relâmpago caiu naquela parte da base onde, até hoje, um jarro de bronze fica como cobertura ${ }^{24}$.

\section{v. Exemplo ou contraexemplo?}

A esta altura, cabe perguntar novamente: como Zeus pode não ter sido, em última instância, copiado de algum modelo sensível? Ele é exemplo de uma arte superior à natureza ou, se analisado impiedosamente, acaba mostrando-se um contraexemplo dessa arte? Será que o fato de ter quinze metros de altura, quando nenhum mortal vai além de três, basta? Suas veias, seus músculos, não seriam um simulacro de alguma veia ou algum músculo sensível? Não será o Zeus de Fídias, no final das contas, um belo Frankenstein? Se o Zeus for mesmo diferente do todos os humanos que habitaram o mundo, e se é um traço nobre do artista não copiar um modelo particular, mas conceber, imaginar a representação de coisas que não existem empiricamente: admitiria Plotino, então, que uma estátua de Tersites, o mais feio dos aqueus em Tróia, seria artisticamente tão valiosa quanto o Zeus?

Penso que há, pelo menos, quatro veredas possiveis para analisar esse exemplo dado por Plotino, uma negativa e três positivas. Passo a expô-las, advertindo, todavia, que são hipóteses ainda incipientes, que têm de ser aprofundadas.

a. Hipótese negativa: uma possibilidade é assumirmos que Plotino não aduza um exemplo satisfatório para sua teoria; seria uma conclusão infeliz, mas os exemplos costumam ser o calcanhar-de-aquiles dos filósofos. Perpassando este artigo, estão vários autores que citam Fídias como exemplo de excelência artística. Eu encontrei mais de duzentas menções diretas ao nome de Fídias somente em autores de língua grega: Fídias não é só um tópos literário e filosófico, mas é o lugar-comum da mestria, é o escultor por antonomásia na literatura antiga. Assim, é possível que Plotino mencione o Zeus de Fídias porque já ouviu ou leu menções a ele um sem-número de vezes e, por conseguinte, esperava que todos seus leitores entendessem tratar-se de um artista e de uma obra sobre-humanos, completamente diferente de tudo mais que se possa encontrar. 0 que não me agrada nesta hipótese é pensar que um filósofo tão profundo, tão vigoroso como Plotino não tivesse previsto essas questões banais que fiz.

b. Hipótese mimético-contemplativa: há dois pilares teóricos para explicar o exemplo através da atividade contemplativa, além da elucidação do
22. Essa é uma questão que merece uma pesquisa à parte. Por ora, contento-me em remeter às breves comparações de Panofsky (1994, 15-34) e Pépin (1992, 331-332).

23. Uma reconstituição detalhada, acompanhada de uma análise minuciosa, é feita por Kerkhecker (1999, pp. 146-181); cf. também Prioux, 2007, pp. 114-121. 24. Pausânias, V, 11, 9 Jones \& Ormerod. 
próprio conceito de contemplação, evidentemente. Em primeiro lugar, é preciso supor uma distinção entre duas miméseis: uma seria a imitação em sentido banal, a cópia exata de um modelo empírico; a outra mímesis teria de ser identificada à theoría: nesta, a cópia não é sensivel nem é exatamente cópia, porque é antes representação, expressão de um lógos. Em segundo lugar, é forçoso estudar essa peça fundamental da metafísica plotiniana que é o lógos: ele é princípio formativo intelectual, a expressão de uma forma inteligível; é o lógos, uma razão seminal, que vai até a matéria e que age na matéria, não o eîdos ${ }^{25}$. 0 Zeus, portanto, seria a mímesis-theoría de um lógos. Eis que surge o grande problema: lógos de quê? De homem? Ou de Zeus? Se de homem, o que distingue a estátua de Zeus, ou a tékhne de Fídias, de outras estátuas, ou da tékhne de outros escultores? Uma dificuldade enorme para esta hipótese é determinar se Plotino acredita ou não na existência das formas particulares ${ }^{26}$.

No que diz respeito à coerência interna do plotinismo, esta talvez seja a hipótese de explicação do exemplo mais bem documentada textualmente, apesar do problema das formas individuais. Entretanto, seu lado negativo é que ela me parece estéril, porque, por um lado, só adquire legitimidade plena dentro plotinismo, parte de Plotino para servir apenas a Plotino; e, por outro, depende desse conceito misterioso, inexplicável, que é a contemplação.

c. Hipótese fantasística: se Plotino acreditasse que Fídias contemplou uma forma inteligível de Zeus e a fez materialmente tal qual, seu platonismo seria uma versão demasiadamente depauperada. Mas, se este não é o caso, como quero crer, há alguma coisa entre a contemplação e a representação, uma faixa nebulosa na qual algo que não existe empiricamente toma uma aparência e uma aparição sensível. 0 comentário de Proclo ao Timeu, citado acima, é mais explícito do que a passagem em Plotino: pois Fídias se inspirou em Homero para fazer sua estátua e nós acrescentaríamos que ele imaginou uma forma humana a partir dessa inspiração homérica. Para nós, hoje, a imaginação é um elemento óbvio da atividade artística, mas o conceito de phantasía, isto é, a capacidade de formar imagens mentais ${ }^{27}$, (ou "na alma", como diriam os antigos), a representação imagética de uma percepção (talvez mais bem compreendido se vertido por "visualização"), sempre esteve associado ao pensamento discursivo e à memória. A noção de mímesis continua a noção preponderante na arte antiga, mesmo em autores como Proclo, em que há uma clara sugestão da phantasía.

Há duas passagens interessantíssimas a esse respeito na Antiguidade. A primeira está em Pseudo-Longino, quando ensina ao seu destinatário, Terenciano, que

As phantasíai são extremamente causadoras de grandeza, magnificência e veemência; nós [plural de autor] as <entendemos> da maneira como algumas pessoas dizem serem elas formações de imagens (eidolopoiíai); comumente se chama phantasía tudo que origina um pensamento que é constitutivo do discurso lógos; mas sobre esse <sentido > já prevalece <0 sentido que tem> a palavra quando pareces ver as coisas que estás dizendo motivado pelo entusiasmo e pela emoção (páthos), e as colocas aos olhos dos que te escutam (Sobre o sublime, 15. 1. 1-15. 2. 1 Russell).

A passagem é bastante difícil, mas nela percebemos que a arte - aqui a arte literária e oratória - começa a apropriar-se do termo phantasía; segundo Pseudo-Longino, o termo costumava ser usado para uma atividade envolvida no pensamento, mas já estava entrando em voga a acepção de que a phantasía é uma faculdade ou atividade que apresenta em forma de imagem o que é dito a partir do enthousiasmós e do páthos; a phantasía coloca para os olhos os sentimentos ouvidos nas palavras.

A segunda passagem está em Flávio Filostrato, bastante conhecida justamente pela dissonância de sua noção de phantasía em relação à maioria dos autores antigos. Na Vida de Apolônio de Tiana, Filostrato conta que Apolônio, visitando os Etíopes, se queixou das formas ridículas e absurdas das suas estátuas divinas, que eram mais desonra do que devoção aos deuses. 0 sábio etíope Tespésio, então, tendo se irritado, pergunta a Apolônio:

“Mas dirás que as vossas estátuas são erigidas como?" "Da maneira mais bela e teófila que deuses 
poder ser feitos (demiourgeîn)", disse <Apolônio>. $E$ <Tespésio> respondeu: "Referes-te ao Zeus em Olímpia, à estátua de Atena, à [de Afrodite] em Cnido, à [de Hera] em Argos e todas quantas são belas e cheias de juventude". "Não apenas essas", disse <Apolônio>, "mas a estatuária de outros povos atém-se ao que é próprio, ao passo que a vossa ridiculariza o divino em vez de acreditar nele". E <Tespésio> perguntou: "Acaso os Fídias e os Praxíteles subiram ao céu e, depois de tomarem as medidas das formas dos deuses, se puseram a fazê-las para si com arte, ou era outra coisa que controlava a modelagem?" “Era outra coisa, repleta de sabedoria", disse <Apolônio>. "Que coisa? Pois não poderias dizer que é outra coisa senão a mímesis", respondeu <Tespésio>. <Apolônio> respondeu: "A phantasía, um artista (demiourgós) mais sábio que a mímesis, fez essas <estátuas>: pois a mímesis produz o que viu, ao passo que a phantasía faz também aquilo que ela não viu, e ela não o fará com referência à realidade [...] Por isso, depois de colocar no espírito (enthymeîsthai: também "conceber", "planejar") a forma de Zeus, é preciso vê-lo com o céu, e com as primaveras, e com os astros, como Fídias se lançou <a fazê-lo>..." (VI, 19, 9-32 Conybeare).

Essa passagem fascinante: Filostrato (ou Apolônio) atribui à phantasía um papel soberano na criação artística, mas ele não está preocupado com o caráter sensível ou inteligível do modelo. Para ele, a phantasía é superior à mímesis porque pode acrescentar ao modelo (real ou não) algo que ele não tinha, tornando-o mais interessante, isto é, mais belo do que se fosse simplesmente copiado a partir de algum modelo concreto; contudo, a obra é sempre copiada: se não da natureza, da alma que o imaginou. Filostrato acredita, pois, que mesmo um modelo irreal como Zeus pode ser melhorado com a phantasía. Mas e Plotino?

Finberg (1926, p. 150) é provocativo: para ele, "estava reservado a Plotino fazer os ajustes metafísicos necessários" para a substituição da mímesis pela phantasía na regência das belas artes, substituição essa que foi "um golpe mortal" para a visão psicológica da arte sustentada por Platão, que foi amparada até então pela influente discussão sobre a mímesis de Aristóteles. Contudo, como ele não vai além disso, tenho curiosidade de saber como ele ajustaria o exemplo dado por Plotino ao uso do conceito de phantasía nas Enéadas. Na passagem de V. 8 [31] citada acima, há indícios de que Plotino tenha em mente um "algo a mais" que a imitação. Como interpretá-lo, quando ele diz que as artes “produzem muitas coisas a partir de si mesmas e acrescentam a essas coisas o que lhes falta"? Há uma ideia bastante próxima da de Filostrato aqui, embora não ocorra o termo phantasía.

A grande inconsistência desta hipótese é que a phantasía, em Plotino, tem exatamente aquele sentido dado acima, da representação envolvida no ato do conhecimento - sobretudo a na percepção sensivel: "a phantasía surge com o golpe externo <à alma> na parte irracional <da alma>" (I. 8 [51] 15. 18) e "a phantasía, a que se chamaria phantasía propriamente, a que é despertada pelas afecções do corpo..." VI. 8 [39] 3. 10-12 $2^{28}$. Mesmo que encontremos usos de phantasía nas Enéadas que não sejam tão determinados pela sensibilidade, ainda persiste o problema de explicar como o Zeus de Fídias não seria produzido por uma phantasía não inspirada pela natureza sensível.

d. Hipótese taumática: o adjetivo desta hipótese provém da palavra grega thaûma, que significa "objeto de admiração, surpresa ou espanto", "admiração", "maravilhamento" etc. Mas, além de seus cognatos, há outras palavras nas Enéadas que exprimem esse tipo de reação da alma diante de algo belo, de modo que, nesta hipótese, todo o vocabulário do desejo, da comoção, da perturbação psíquica e somática deve ser investigado, a fim de evidenciar-se a experiência da alma diante da beleza. Uma bela passagem do tratado Sobre o belo ajuda a dar início à circunscrição desta minha hipótese:

“Estas afecções ( $\pi \alpha \dot{\theta} \theta \eta)$ devem surgir ante tudo que seja belo: assombro ( $\theta \alpha \dot{\alpha} \mu \beta \mathrm{\beta})$, doce tremor

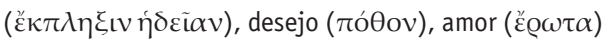

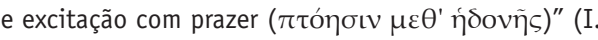
6 [1] 4. 15-17).

Vislumbrar a intensidade dessa experiência demanda-nos certo exercício, pois parecemos
8. Sobre a phantasía em Plotino cf. Warren, 1966, e Blumenthal, 1971, pp. 80-99 
ter-nos esquecido do que é desejar o belo com tal intensidade. Do belo como objeto do juízo de satisfação desinteressada do gosto (Kant, Crítica da faculdade de julgar, § 5) à kalliphobia ${ }^{29}$ da arte contemporânea, a comoção platônico-plotiniana diante da beleza parece não situar-se mais no terreno da estética; ela parece pertencer agora ao campo da patologia e encontrar intensidade semelhante apenas nos impulsos sexuais. 0 plano de Platão (Fedro, Banquete) e de Plotino (I. 6 [1]) não é a repressão desse arrebatamento, mas o seu correto direcionamento: como insiste Plotino, e a citação de V. 8 [31] 1 o ilustra, a beleza não está na matéria, mas na forma; quanto mais forma e menos matéria, mais beleza, e a beleza em si mesma é o inteligível em si mesmo. 0 arrebatamento, a comoção, esse desejo impossível de ser contido, é o melhor impulso para a filosofia.

De volta à hipótese: aqui, o caminho seria interpretar o Zeus de Fídias, não como a representação de uma forma, seja ela sensivel ou inteligível, mas como a reprodução da comoção diante da beleza em si mesma, que só pode ser inteligível: o encontro com a magnificência da estátua seria a reativação do arrebatamento, ou seja, não se trata mais de copiar ou imaginar o modelo, mas de reavivar a experiência da contemplação da beleza. A ênfase, assim, não está em Fídias ter contemplado um lógos inteligível, mas no maravilhamento excitado por essa experiência. Talvez, nenhum encontro com nenhuma beleza natural, ou copiada de um modelo empírico tal qual, poderia causar a mesma comoção que causa o Zeus, tanto pelo tamanho exagerado, quanto pela resplandecência e pela perfeição dos detalhes. A citação daquela passagem de Pausânias indica exatamente essa ideia: a informação das medidas exatas da estátua não faz jus à impressão daqueles que a veem. É como uma fotografia em alta resolução do Taj Mahal: nos mostra perfeitamente como ele é, mas não reproduz a experiência de visitá-lo.

Como nas outras, há muitas dificuldades também nesta hipótese, sem dúvida. A bem da verdade, a dificuldade inicial permanece: mesmo que se trate da reprodução do encontro com a beleza (que por definição é inteligível), como a estátua não seria uma cópia de algum modelo sensível ou de partes de vários modelos sensíveis? E mais: é o tamanho colossal da estátua que provocaria o arrebatamento ou sua perfeição? Se é o tamanho, que é uma característica sensivel, então a estátua ainda tem uma inspiração sensível? Se é a perfeição, Plotino concordaria que uma estátua diminuta de Zeus teria o mesmo valor artístico? Se é a perfeição, ainda, trata-se da perfeição da simetria, da reprodução acurada de proporções? Mas como conciliar isso com a crítica à identificação da beleza com a simetria em I. 6 [1] 1? Certo, a beleza não pode ser reduzida à simetria, pois coisas simples podem ser belas; e, neste caso, estamos tratando de uma estátua, que é o resultado de uma tékhne: então o caráter inteligível da execução artística não precisa necessariamente resultar numa obra perfeita em simetria? Mas, se o Zeus de Fídias fosse ainda maior e mais resplandecente, mas tivesse falhas de acabamento, ele continuaria arrebatando aqueles que o veem?

Seria possível, com isso, situar Plotino na querela personificada por Calímaco, crítico da arte colossal e defensor-praticante da arte lépida, e Apolônio de Rodes, defensor das epopeias e praticante da arte majestática, uma querela estética que se estendeu pela Antiguidade e que também foi acalorada em Roma? Pensaria Plotino que a beleza pode manifestar-se de muitos modos, mas que a arte deve ser majestática tanto em tema quanto em execução? Teria ele alguma afinidade com Pseudo-Longino, para quem o homem se interessa e admira, naturalmente, a grandiosidade?

Então, que viram esses homens iguais a deuses e que alcançam os cumes da literatura, mas que desprezaram a exatidão de todos os detalhes? Além de muitas outras coisas, isto: que a natureza não fez o homem para ser uma criatura humilde e ignóbil, mas, tendo-o trazido à vida e a todo o cosmo como se a um grande festival para ser um espectador das competições e também um agonista amante de honrarias, ela incutiu em nossas almas um eros irresistivel por tudo que é sempre grandioso e, em relação a nós, mais divino (daimonióteros). Por isso, nem mesmo o cosmo inteiro basta para a apreensão da especulação e do pensamento humanos [...] (Sobre o sublime, 35.2.1-35.3.3).

Todavia, apesar de suas muitas dificuldades, 
esta hipótese me parece interessante por tentar explorar um deslocamento da fenomenologia da beleza: passar da reflexão acerca da obra de arte para a reflexão acerca da experiência estética. Porém parece que continuamos incapazes de explicar por que Fídias não teria copiado um modelo sensível.

Algo que pode ser promissor, para este hipótese, aproveitando a menção a Pseudo-Longino, é buscar apoio em sua noção de sublime, estendendo-a da literatura até a arte em geral. Essa noção é indefinível (mas não inatingível) e pode manifestar-se num verso, numa metáfora ou mesmo num silêncio: o sublime é o eco de uma mente elevada, por isso o silêncio de Ájax na Nékyia (Odisséia, 11, 563) é mais eloqüente e elevado do que qualquer palavra. A semelhança com a hipótese em Plotino é que 0 sublime está mais na experiência estética do que na obra, embora seja suscitado pela obra, e é experiência descrita com ideia e palavras semelhantes à comoção diante da beleza em Plotino:

Pois a grandeza não conduz o ouvinte à persuasão, mas ao êxtase; e o maravilhoso (

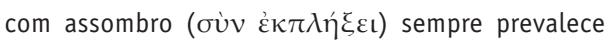
completamente sobre o persuasivo e o gracioso, pois 0 persuasivo está no mais das vezes sob nosso controle, enquanto que eles [o maravilhoso e o assombro], trazendo dominação e força invencíveis, se colocam acima [i.e. dominam] dos ouvintes; não vemos a experiência na invenção e a ordenação e economia dos assuntos em uma ou duas passagens, mas elas se revelam a partir de todo o texto; mas o sublime, produzido no momento certo, atravessa todas as coisas como um raio e exibe toda a força do orador imediatamente (I. 4. 1).

Algo óbvio: a arte de Fídias produz o sublime. Mas, no caso de Pseudo-Longino, não existe nenhuma referência à inteligibilidade ou sensibilidade do modelo para a mímesis produtiva do sublime. Mas, para Plotino, se é possível de fato ver um eco desse conceito na passagem de V. 8 [31] 1, o sublime seria produzido apenas a partir da contemplação do inteligivel.

Como adverti no início, a intenção deste artigo é somente questionar a validade do exemplo dado por Plotino para uma arte que imita o sensível.
Espero, dessa forma, ter logrado expor os motivos pelos quais esse exemplo me parece insatisfatório e esboçar algumas hipóteses de entendê-lo. Cabe agora estudar com mais profundidade o exemplo à luz dessas hipóteses e, certamente, encontrar outras mais.

\section{REFEÊNCIAS BIBLIOGRÁFICAS}

ALLIEZ, E. 1991, Tempos Capitais: relatos da conquista do tempo, São Paulo, Ed. Siciliano.

AUBENQUE, P. 1973, "Plotino e o Neoplatonismo", in CHÂTELET 1973, História da Filosofia, vol. 1: A filosofia pagã, Rio de Janeiro, Zahar Editores, 199-234.

BARACAT, J., jr. 2002, "Aspectos da contemplação plotiniana", Phaos, 2, pp. 5-34.

BARACAT, J., jr. 2007, “ A legitimidade da arte na filosofia de Plotino", Calíope, 16, pp. 72-82.

BESANÇON, A. 1997, A imagem proibida: uma história intelectual da iconoclastia, Rio de Janeiro, Bertrand Brasil.

BLUMENTHAL, H. 1966. “Did Plotinus Believe in Ideas of Individuals?", Phronesis, 11, pp. 61-80.

1971. Plotinus' Psychology: His Doctrine of the Embodied Soul, The Hague, Martinus Nijhoff.

BRÉHIER, E. 1924-1938, Plotin, Ennéades (7 vols.), Paris, Belles Lettres.

BUFFIÈRE, F. 1973, Les mythes d' Homère, Paris, Belles Lettres.

DANTO, A. 2004, "Kalliphobia in contemporary art", Art Journal, 63, n² 2, 24-35.

DELEUZE, G. 1969, Logique du sens, Paris, Minuit.

FINBERG, 1926, "The Filiation of Aesthetic Ideas in the Neoplatonic School", The Classical Quarterly, 20, № 3/4, pp. 148-151.

HALLIWELL, S. 2009, "Aesthetics in Antiquity", in S. DAVIES et al. (org.), A Companion to Aesthetics, 0xford, Blackwell, pp. 10-22.

HENRY, P. and R.-H. SCHWYZER 1964-1982, Plotini Opera (3 vols.), 0xford, OUP.

IGAL, J. 1992, Plotino, Enéadas (3 vols.), Madrid, Gredos.

KERKHECHER, A. 1999, Callimachus's Book of Iambi, Oxford-New york, OUP.

KEYSER, E. 1955. La significarion de l' art dans les Ennéades de Plotin, Lovain.

LOMBARDO, G. 2002, L'estetica antica, Bologna, Il Mulino.

NEHAMAS, A. 2007, Only a Promise of Happiness, Princeton, PUP.

PANOFSKY, E. 1994, Idea, São Paulo, Martins Fontes.

PÉPIN, J. 1992, "L'épisode du portrait de Plotin", in 
BRISSON et. al., La vie de Plotin, Paris, Vrin, pp. 301-334. PRIOUX, E. 2007, Regards Alexandrins, Louvain, Peeters.

RUSSELL, D. A. 1964, Longinus' On the Sublime, 0xford, OUP.

2003, "Greek Criticism of the Empire", in G. Kennedy (ed.), The Cambridge History of Literary Criticism, vol. 1, Cambridge, CUP, pp. 297-329.

SCHUHL, P. 1933, Platon et l'art de son temps, Paris, Alcan.
STERN-GILLET, S. 2002, "Plotinus", in C MURRAY (ed.), Key Writers on Art, London, Routledge.

2003, "Neoplatonist Asthetics", in P. SMITH (ed.), A Companion to Art History, 0xford, Routledge, pp. 40-48.

WARREN, E. 1966, "Imagination in Plotinus", The Classical Quarterly, 6, 2, pp. 277-285.

Recebido em março de 2012 e aprovado em março de 2012 